\title{
Phylogenetic analysis of avian infectious bronchitis virus S1 glycoprotein regions reveals emergence of a new genotype in Moroccan broiler chicken flocks
}

Siham Fellahi ${ }^{1}$, Mehdi EL Harrak ${ }^{2}$, Mariette Ducatez ${ }^{3,4}$, Chafiqa Loutfi ${ }^{2}$, Saad Ibn Souda Koraichi ${ }^{5}$, Jens H. Kuhn ${ }^{6}$, Slimane Khayi ${ }^{7}$, Mohammed EL Houadfi ${ }^{1}$ and My Mustapha Ennaji $i^{*^{*}}$

\begin{abstract}
Background: Infectious bronchitis virus (IBV), a major pathogen of commercial poultry flocks, circulates in the form of several serotypes/genotypes. Only a few amino-acid changes in the S1 subunit of wild-type IBVS proteins may result in mutants unaffected by current vaccines.

Methods: Partial S1 gene sequences of 3 IBV isolates of the Moroccan Italy 02 genotype from vaccinated and unvaccinated broiler chicken flocks, located in southern and central regions of Morocco, were amplified by RT-PCR, sequenced, and aligned for phylogenetic and amino-acid similarity analyses.

Results: The three isolates were found genetically highly distant from known avian IBV based on partial sequences of their S1 genes: gammaCoV/chicken/Morocco/I01/2011(IBV/Morocco/01), gammaCoV/chicken/Morocco/l30/2010 (IBV/Morocco/30), and gammaCoV/chicken/Morocco/I38/2013 (IBV/Morocco/38), nucleotide sequence identities reached $89.5 \%$ to $90.9 \%$ among the three isolates. The deduced protein sequence identities ranged from $29.7 \%$ (between IBV/Morocco/38 and Egypt SCU-14/2013-1) to 78.2 \% (between IBV/Morocco/01 and Spain/05/866). Amino acid sequence comparison and phylogenetic analysis indicated the emergence of a new Moroccan genotype, clustering with regionally related isolates from Spain (Spain/05/866) and belonging to a new sub-genotype.

Conclusion: Our sequencing results demonstrate a co-circulation of wild-type infectious bronchitis viruses in broiler chickens. These results justify permanent monitoring of circulating strains in order to rationally modify vaccination strategies to make them appropriate to the evolving field situation.
\end{abstract}

Keywords: Infectious bronchitis virus, Phylogenetic analysis, New genotype, Morocco

\section{Introduction}

Infectious bronchitis (IB) is one of the most contagious diseases that affect poultry worldwide and is responsible for severe economic losses. Clinically, the disease causes respiratory distress, drop in egg production and quality

\footnotetext{
* Correspondence: m.ennaji@yahoo.fr

${ }^{\dagger}$ Equal contributors

${ }^{8}$ Laboratoirede Virologie, Microbiologie et Qualité/ETB- Faculté des Sciences et Techniques, Mohammedia, Université Hassan II- Casablanca, Mohammedia 20650, Morocco

Full list of author information is available at the end of the article
}

in layers. Some strains of IBVare associated with nephritis [1-3].

Infectious bronchitis virus (IBV) is a member of the species Avian coronavirus, genus Gammacoronavirus (Nidovirales: Coronaviridae: Coronavirinae) [4]. IBV has a linear, single-stranded RNA genome of positive polarity of approximately $27 \mathrm{~kb}$ in length and produces enveloped virions. IBV particles consist of three major structural proteins: spike (S) glycoprotein, membrane $(\mathrm{M})$ protein, and nucleocapsid $(\mathrm{N})$ protein. The spike of IBV is formed by post-translational cleavage of $\mathrm{S}$ into two separate polypeptide components, S1 and S2 [5, 6]. S1 mediates virion attachment to IBV host cells and is a 
major target of neutralizing antibodies in chickens. Genotype evolution of IBV is associated primarily with changes in the S1amino-acidsequence [7, 8]. Hence, the evolutionary characterization of IBV is mainly based on the analysis of the variable S1 gene or the expressed S1 protein $[9,10]$.

Different IBV variants are distributed globally. Some of these variant are endemic only in particular regions, while others circulate worldwide [11]. More than 20 different IBV serotypes are differentiated worldwide that evolved from genomic insertions, deletions, substitutions, and/or RNA recombinations of the S1 gene [12-14]. This large diversity of serotypes is a major reason why commercial vaccines often fail or are only partially efficacious, and, therefore, new IB outbreaks continue to occur [1].

The first isolation and characterization of IBV from poultry flocks in Morocco was reported by El-Houadfi et al. in 1986 [15]. Six isolates were obtained, of which isolates designated $\mathrm{D}, \mathrm{E}, \mathrm{F}, \mathrm{H}$, and $\mathrm{M}$ were found to be serologically related to the Massachusetts (Mass) serotype, whereas the sixth isolate, G, differed from the Mass serotype and other serotypes known at the time. Importantly, El-Houadfi et al. demonstrated that Mass-based IBV vaccines provided poor protection against infection with isolate G [15]. In 2004, Alarabi conducted a study to determine the relationship between IBV and nephropathogenic disease outbreaks observed in broiler flocks in Morocco between 1996 and 2000. Three different groups of IBV isolates were identified using RT-PCR coupled with restriction fragment length polymorphism (RFLP). Group I belonged to the Mass serotype, whereas groups II and III were distinct. Isolate $12 / 97$ of group III, found to be closely related to isolate $\mathrm{G}$, caused more severe kidney lesions and higher lethality in experimentally infected animals compared to isolate $7 / 97$ of group II [16]. In 2005, El Bouqdaoui et al., while studying nephropathogenic IBV using RT-PCR and RFLP techniques, identified five genotypes, three of which differed from vaccine strains [17].

The Moroccan poultry industry has developed significantly under the framework "Plan Green Morocco" and meets the growing domestic consumer demand for poultry products, including meat and eggs The industry generates a turnover of around 30 billion dirhams/year, totaling mean investments of around 8.7 billion dirhams/year. The official data regarding the general poultry rearing systems in Morocco are: broiler production, 450 million/year (among 6,800 farms); layers: 20 million/year (250 farms); turkeys: 12 million/year ( $25 \%$ imported d-old chicks); broiler breeders: 3.2 million/year (70 \% imported from Spain and 30 \% from other European countries); 48 hatcheries. The Interprofessional Federation of Poultry Sector (FISA) aims to develop exports of poultry products in particular to Northern and Western Africa. FISA is affiliated with Association of Moroccan Exporters (ASMEX) under the objective of promoting poultry product export in Africa, including chicks, hatching eggs, and compound feed for poultry. In 2012, 6.7 million hatching eggs and 1.9-million-d-old chicks were exported to Mauritania, Mali, Cameroon, Côte d'Ivoire, and Senegal, and 25,000 tons of compound feed were exported to Mauritania. Breeder chicks $(182,000)$ were imported in January 2014 (an increase of $28 \%$ compared to 2013). However, imports of layer and broiler breeder and turkey poults declined in recent years, mainly due the development of local production.

Three IBV vaccines are used in Morocco to protect the industry: 793B, Arkansas, and Mass. The Mass type has been used as of 1970 (H120, Ma5, and modified Mass strains), whereas 793B (4/91 and CR88 strains) and Arkansas vaccines were introduced in 2000 and 2013, respectively. New IBV serotypes and genotypes can emerge as a result of only very few changes in the amino acid sequence of the $S$ protein. Vaccination programs largely rely on the use of the IBV Massachusetts strain, which is also the most commonly used IBV vaccine strain in Morocco. However, despite the use of this vaccine, the common presences of IB in vaccinated chickens continue to have a major negative economic impact [18]. In this study, IB was diagnosed between January 2010 and December 2013 in southern and central regions of Morocco. Suspected IBV infections were found in 47 commercial broiler chicken farms. Among these, three flocks showed severe clinical signs and mortality. The aim of the present study is to characterize a new emerging genotype of IBV from these outbreaks using molecular techniques, and to determine the relationship to reference IBV strains by nucleotide sequence analysis.

\section{Results}

Case history

Infectious bronchitis was diagnosed between January 2010 and December 2013 in southern and central regions of Morocco. Suspicious IBV infections (prominent respiratory disease) were found in broiler chickens from 47 commercial farms. The flocks had been vaccinated against Newcastle disease and infectious bursal disease (Table 1). Among these farms, three flocks had severe respiratory signs and experienced increased mortality. The first flock, located in southern Morocco (Marrakech), was $26 \mathrm{~d}$ old and was the only flock that had been vaccinated with the H120 live IB vaccine by spray on $\mathrm{d} 7$ and 21 . The second flock, located in central Morocco (Khamisset), was $24 \mathrm{~d}$ old, and the third flock, located also in central Morocco (Rabat) was $20 \mathrm{~d}$ old. Clinical presentation started with respiratory depression and distress, including nasal discharge, sneezing, coughing, and rales. Other signs included conjunctivitis and watery eyes. Within $10 \mathrm{~d}$ after 
Table 1 Characterization of Moroccan infectious bronchitis virus isolates from broiler chickens

\begin{tabular}{|c|c|c|c|c|}
\hline $\begin{array}{l}\text { Isolate } \\
\text { designation }\end{array}$ & Age, $d$ & $\begin{array}{l}\text { Time of } \\
\text { vaccination, } \\
d \text {, and } \\
\text { (virus vaccine) }\end{array}$ & Date of isolation & $\begin{array}{l}\text { GenBank } \\
\text { accession no. }\end{array}$ \\
\hline \multirow[t]{3}{*}{ Moroccan 30} & 26 & 7 and $21(\mathrm{IBV})^{\mathrm{a}}$ & May 2010 & KJ701020 \\
\hline & & $14(\mathrm{NDV})^{\mathrm{b}}$ & & \\
\hline & & $18(\mathrm{IBDV})^{\mathrm{C}}$ & & \\
\hline \multirow[t]{2}{*}{ Moroccan 38} & 24 & $7\left(\mathrm{NDV}^{\mathrm{b}}\right.$ & December 2013 & KJ701019 \\
\hline & & $22\left(\mathrm{IBDV}^{\mathrm{c}}\right.$ & & \\
\hline \multirow[t]{2}{*}{ Moroccan 01} & 20 & $5(\mathrm{NDV})^{\mathrm{b}}$ & April 2011 & KM594187 \\
\hline & & $18(\mathrm{IBDV})^{\mathrm{c}}$ & & \\
\hline
\end{tabular}

${ }^{\mathrm{a}} \mathrm{IBV}=$ Infectious bronchitis virus, ${ }^{\mathrm{b}} \mathrm{NDV}=$ Newcastle disease virus,

${ }^{\mathrm{C}} \mathrm{BDDV}=$ Infectious bursal disease virus

the appearance of the disease, lethality increased from $10 \%$ to $30 \%$ of the total flocks. Post-mortem examination of dead birds revealed increased tracheal mucus, slight congestion, and presence of catarrhal exudates in the nasal turbinate and trachea.

\section{IBV isolation and identification}

We obtained a total of 47 Moroccan field isolates of IBV from the 47 affected farms and were able to distinguish them based on sequences of the hypervariable region (HVR) 3 of their S1 regions (nucleotides 700-1095). Of those isolates, three isolates, classified as the Moroccan Italy 02 genotype, underwent further sequencing to include all three hypervariable S1regions (nucleotides 11,095). These three IBV strains were isolated from trachea, lungs, and kidneys of broiler chickens. Between the first and fourth passage, virus propagation from the three suspect samples in specific pathogen-free eggs resulted in characteristic IBV lesions (e.g., curled and dwarfed embryos with head pressed over the feet and covered by a thickened amnion)in $90 \%-100 \%$ of the embryos. Results of both RT-PCR targeting the IBV N gene and RT-PCR using primers amplifying a partial sequence of the IBV S1 gene were positive, confirming the identity of the three isolates. The amplified partial S1 fragments (approximately $700 \mathrm{bp}$ in length) of the three isolates were sequenced. The sequences were submitted to GenBank and assigned the accession numbers KJ701019, KJ701020 and KM594187 for isolates gammaCoV/chicken/ IBV/Morocco/I38/2013 (IBV/Morocco/38), gammaCoV/ chicken/IBV/Morocco/I30/2013 (IBV/Morocco/30), and gammaCoV/chicken/IBV/Morocco/I01/2013 (IBV/Morocco/ 01 ), respectively (Table 1 ).

\section{Sequence analysis}

Partial S1 gene sequences of the three IBV isolates were sequenced. The nucleotide sequence and deduced amino acid sequences (Table 2) of these IBV isolates were blasted and compared with the reference and variant strain sequences retrieved from GenBank from different regions of the world. IBV isolates (IBV/Morocco/30, IBV/Morocco/38, and IBV/Morocco/01) were found to have different and unique partial S1 sequences compared to reference strains. The sequences of the three isolates have a nucleotide sequence identity between $91.6 \%$ (IBV/Morocco/38 and IBV/Morocco/01) and $94.8 \%$ (IBV/Morocco/30 and IBV/Morocco/01) when compared to each other and from $29.7 \%$ (IBV/Morocco/38 or IBV/Morocco/30 and Egypt SCU-14/2013-1)to $78.2 \%$ (IBV/Morocco/01 and Spain/05/866) when compared to non-Moroccan IBV strains.

The deduced amino-acid sequence identities of Moroccan IBV isolates ranged from89.4 \% (between IBV/Morocco38 and IBV/Morocco/01) to $90.9 \%$ (between IBV/Morocco/38, IBV/Morocco/30and IBV/Morocco/01) when compared to each otherand from $12.9 \%$ (between IBV/Morocco/38 and Egypt SCU-14/2013-1)to 76.8 \% (between IBV/Morocco/30 and Spain/04/22-1 of the Spanish Italy 02 genotype), [19] when compared to non-Moroccan IBV strains (Table 2). The alignment of the Moroccan IBV isolates amino-acid sequences with that of reference strain H120 identified the most variable regions in residues 6277 and 117-131 (numbering in reference to the H120 strain, Fig. 1). Insertions in the partial S1 subunit of the three Moroccan strains were found at positions119, 120, 143, and 144 (Fig. 1).

The partial S1 protein sequences of the Moroccan isolates were $69.4 \%$ to $76.8 \%$ homologous to those from genotype Italy-02 (Italy 02 [AJ457137]; Italy 497/02-1 [DQ901377]; Spain/05/866 [DQ386102]; Spain/04/22-1 [DQ386100]; Spain/04/221[DQ386103]) but were <66.5 \% homologous to the remaining reference strains (Table 2).

Phylogenetic trees were constructed from the nucleotide and deduced amino-acid sequences of the partial S1 glycoprotein genes of Moroccan IBV isolates and nonMoroccan IBV referenced strains. The three Moroccan IBV isolates and Spanish isolates of the Italy 02 genotype formed a common branch (Fig. 2), but they clearly clustered into 2 distinct sub-genotypes within the group. The sequence analysis of the partial S1 gene demonstrated that Moroccan isolates represent a unique subgenotype compared to other reference strains of various countries and are distantly related to African, European, and American strains.

\section{Discussion}

IBV was detected in poultry in Morocco in the 1980s, and in more recent years, outbreaks of IB were reported repeatedly [15-17]. The present study suggests that a new genotype, represented by the three new IBV isolates described here, has been circulating in Morocco since at least 2010 (IBV/Morocco/30, accession number: KJ701020). 
Table 2 Nucleotide and amino acid identities of IBV Moroccan isolates and reference strains

\begin{tabular}{|c|c|c|c|c|c|c|c|c|c|c|c|c|c|c|c|c|c|c|c|}
\hline \multirow[b]{2}{*}{ Strains } & \multicolumn{19}{|c|}{ S1 gene nucleotide identity (\%) } \\
\hline & 1 & 2 & 3 & 4 & 5 & 6 & 7 & 8 & 9 & 10 & 11 & 12 & 13 & 14 & 15 & 16 & 17 & 18 & 19 \\
\hline 1. IBV/Morocco/38 & 100 & 93.5 & 91.6 & 74.3 & 74 & 73.8 & 73.2 & 72.6 & 65.6 & 61.8 & 62 & 56.1 & 61.5 & 53 & 46.3 & 62 & 31.5 & 29.7 & 31.5 \\
\hline 2. IBV/Morocco/30 & 90.9 & 100 & 94.8 & 77.7 & 77.7 & 77.4 & 76.7 & 76.2 & 68.7 & 65.2 & 65.4 & 58.5 & 65.1 & 49.5 & 48.2 & 65.4 & 31.46 & 29.7 & 33 \\
\hline 3. IBV/Morocco/01 & 89.4 & 90.9 & 100 & 78.2 & 77.8 & 77.8 & 76.8 & 76.3 & 69.9 & 65 & 65 & 59.1 & 65.7 & 48.8 & 49.3 & 65 & 33.7 & 31.8 & 33.7 \\
\hline 4. Spain/05/866 & 73.6 & 75.8 & 75.6 & 100 & 98.3 & 98.3 & 93.7 & 92.9 & 77.5 & 71.3 & 71.6 & 63.9 & 71.6 & 41.6 & 52.9 & 71.6 & 75.2 & 35.5 & 37 \\
\hline 5. Spain/04/22-1 & 73.2 & 76.8 & 74.6 & 96.5 & 100 & 97.7 & 93.9 & 93.5 & 78.1 & 70.8 & 71 & 63.7 & 71.4 & 41.8 & 52.7 & 71 & 75.2 & 35.5 & 37 \\
\hline 6. Spain/05/221 & 72.7 & 76.3 & 75.1 & 95.4 & 94.8 & 100 & 93.1 & 93.1 & 78.2 & 71.4 & 71.6 & 64.3 & 71.6 & 42.1 & 53.1 & 71.5 & 75 & 35.7 & 37 \\
\hline 7. Italy-02 & 71.3 & 74.8 & 73.6 & 89.7 & 91.4 & 89.7 & 100 & 97.1 & 74.6 & 71 & 71.2 & 65.1 & 69.8 & 4.3 & 52.3 & 71.2 & 73.3 & 35.3 & 36.4 \\
\hline 8. It/497/02-1 & 69.4 & 73.3 & 71.6 & 90.2 & 92 & 91.4 & 93.1 & 100 & 75.6 & 70.4 & 70.6 & 64.2 & 70.4 & 41.8 & 52.1 & 70.6 & 74.1 & 34.9 & 35.7 \\
\hline 9. 4/91 & 63.6 & 65.3 & 66.5 & 76.1 & 76.1 & 76.7 & 72.2 & 72.2 & 100 & 74.14 & 74.3 & 60.6 & 73.4 & 38.4 & 48.9 & 74.3 & 71.5 & 34.9 & 35.9 \\
\hline 10. H120 & 58.8 & 61.8 & 61.4 & 68.4 & 67.2 & 66.1 & 66.1 & 64.9 & 65.3 & 100 & 99.4 & 61.1 & 72.2 & 35.9 & 45.9 & 99.4 & 69.2 & 33.1 & 35 \\
\hline 11. Ma5 & 59.3 & 62.3 & 61.9 & 68.9 & 67.8 & 66.7 & 66.7 & 65.5 & 65.3 & 99.4 & 100 & 61.3 & 72.4 & 36.1 & 46.1 & 100 & 69.3 & 33.1 & 35 \\
\hline 12. D274 & 55.1 & 57.3 & 58.4 & 66.5 & 65.9 & 67 & 67.6 & 65.9 & 61.9 & 58.9 & 58.9 & 100 & 58.8 & 33.8 & 42.4 & 61.3 & 61.1 & 27.9 & 29.5 \\
\hline 13. Qx & 60 & 62 & 62.6 & 68.9 & 67.8 & 66.7 & 67.8 & 66.1 & 69.3 & 72 & 72.6 & 60.2 & 100 & 37.3 & 47.9 & 72.4 & 70.2 & 32.1 & 32.8 \\
\hline 14. TN556/07 & 52.7 & 48.5 & 48.1 & 42.1 & 42.5 & 42.9 & 40.8 & 42.1 & 41 & 34.4 & 34.9 & 36.1 & 37.4 & 100 & 58.7 & 36.1 & 38.7 & 22 & 22.2 \\
\hline 15. TN296/07 & 37.3 & 38.6 & 39.5 & 45.9 & 44.8 & 44.8 & 44.5 & 44.3 & 43.7 & 38.5 & 39 & 38.2 & 40.7 & 41.6 & 100 & 46.1 & 49.2 & 28.2 & 28.5 \\
\hline 16. NGA/A116E/2006-1 & 59.3 & 57,9 & 60,41 & 68.9 & 67.8 & 66.7 & 66.7 & 65.5 & 65.3 & 99.4 & 99.4 & 58.9 & 72.6 & 34.9 & 39 & 100 & 69.3 & 33.1 & 35 \\
\hline 17. Ark/C6d & 61.3 & 63.8 & 61.9 & 73.7 & 73.7 & 73.2 & 72.1 & 72.1 & 67.1 & 63.9 & 64.4 & 62.5 & 68.9 & 39.4 & 42.4 & 64.4 & 100 & 34.5 & 36.4 \\
\hline 18. Egypt/SCU-14/2013-1 & 12.9 & 14.5 & 13.6 & 16.9 & 17.5 & 16.9 & 16.4 & 16.4 & 14.3 & 16.5 & 17 & 12.6 & 17.1 & 10.4 & 11.6 & 17 & 16.1 & 100 & 81.8 \\
\hline \multirow[t]{2}{*}{ 19. Egypt/Beni-Suef/01 } & 13.8 & 14 & 14.6 & 18 & 18.6 & 18 & 17.5 & 17.5 & 15.4 & 17 & 17.6 & 14 & 18.8 & 10.7 & 11.4 & 17.6 & 17.2 & 81.3 & 100 \\
\hline & \multicolumn{19}{|c|}{ S1 protein amino acid identity (\%) } \\
\hline
\end{tabular}

Phylogenetic analyses comparing the partial S1 gene sequences of the three Moroccan field isolates with those of reference and variant strain sequences revealed that the Moroccan isolates were $69.4 \%$ to $76.8 \%$ homologous with Spanish isolates of the Italian 02 genotype [19]. This similarity can be explained by the geographical proximity and close transboundary of Morocco and Spain. Moreover, these two countries have an ancient history of commercial exchanges. In addition, Spain is the most frequent country that exports breeder chicks to Morocco (exports areunder the control of Office National de Sécurité Sanitaire des ProduitsAlimentaires, http://www.onssa.gov.ma/).

The deduced amino-acid sequences of Moroccan IBV isolate proteins demonstrated that the Moroccan isolates represent a unique genotype compared too ther reference strains of various countries. These Moroccan isolates are only distantly related to African, European, and American strains. The origin of this novel genotype remains to be identified. In addition to population diversity [20-22], widespread use of various vaccines made from heterotypicIBVs in the field, recombination as a consequence of mixed infections, or a decrease of dominant serotypes as a result of vaccination may play important roles in the emergence of such novel genetic variants in Morocco.
Alignment of the partial S1 glycoprotein sequence of Moroccan IBV isolates with thatof published nonMoroccan IBV strain, H120, identified most sequence variations between residues $62-77$ and 117-131 (Fig. 1). Both of these sequence regions correspond to known HVR, mainly HVR1residues 50-69, and HVR2, residues 117-131, of the IBVS1 gene. HVR1 and HVR2 contain sequences that have been associated with specific IBV serotypes $[7,23]$ andserotype-specific neutralizing epitopes [8]. The nucleotide S1sequences of IBV serotypes commonly differ by 20 to $25 \%$ [24], but amino acid S1 sequences of some serotypes differ by as little as $2 \%$ [25]. The HVRs are associated with two separate viral neutralizing and conformationally-dependent epitopes [7, 26].

The insertions of four amino acids in the S1 subunit of the three Moroccan strains possibly havesome significance relatedto S1 functions (e.g., neutralization phenotypes, virus tropism) [7, 25, 27-29]. Further studies are needed to determine the role of theseinsertions in the $\mathrm{S}$ glycoprotein [30], which might be related to reported changes in the clinical manifestations of IB.

In the phylogenetic tree shown in Fig. 2, the Moroccan IBV isolates formed a distinct cluster withthe Spanish isolates of the Italy 02 genotype (supported by a high bootstrap value: 96). The Spanish IV genotype was previously established as a new genotype based on the 


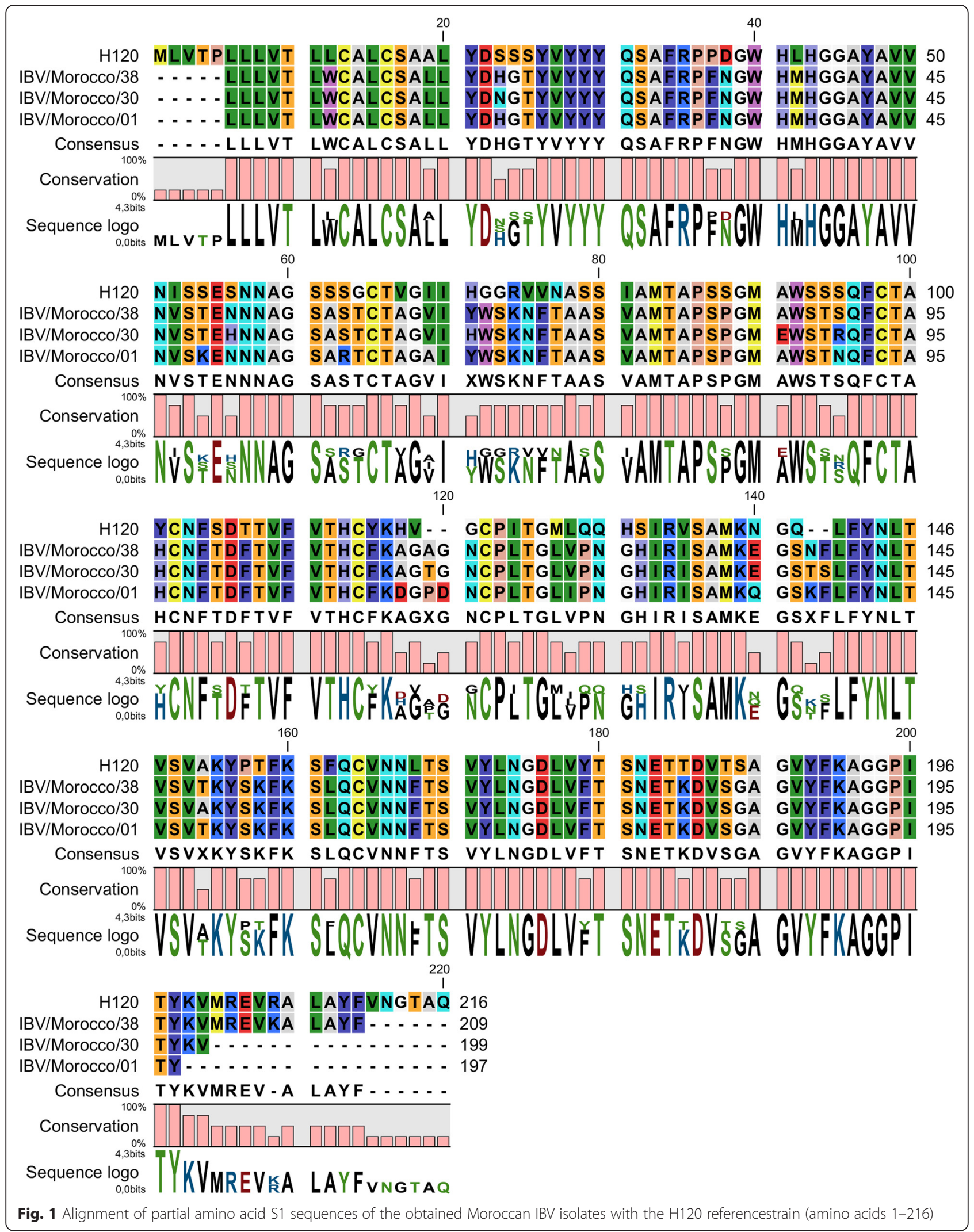




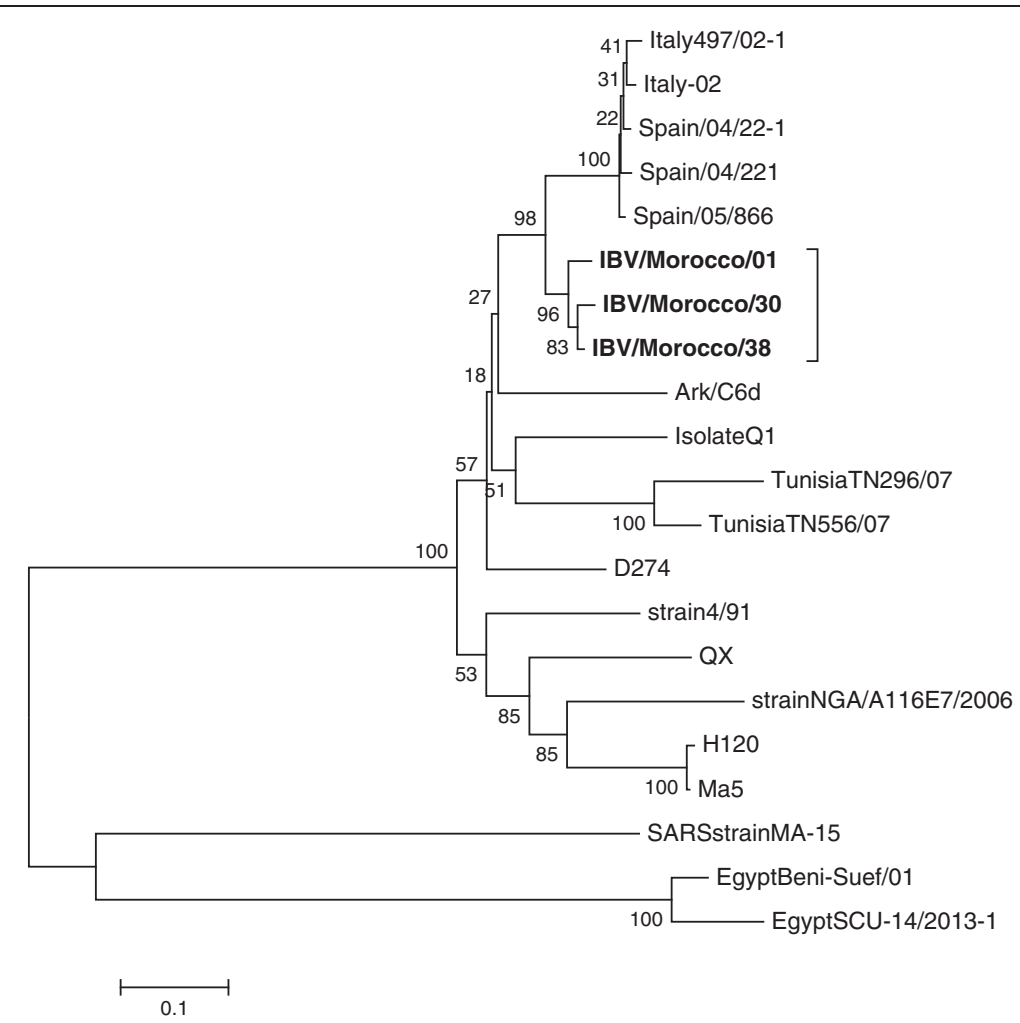

Fig. 2 Phylogenetic relationships of the obtained Moroccan isolates and selected reference strains based on partial S1 nucleotide sequences determined using MEGA 5.0 with the Clustal W method. Numbers along the branches refer to bootstrap values

mosaic nature of its S1 gene. Viral neutralization studies revealed Italy 02 and Spanish IV genotypes are subtypes within a common serotype [19].

\section{Conclusion}

This molecular study has revealed that a new genotype can emerge as a result of only a few changes in the amino acid composition in the S1subunit of the virus Sprotein [25]. This is the first report of identification and genotyping of emergent IBV isolates in Morocco, which indicate the circulation of previously unknown IBV variants in both vaccinated and unvaccinated broiler chickens.

Our data provide evidence of a new emerging genotype in Morocco. Three IBV field isolates were different from published referenced strains in nucleotide and amino acid sequences and clustered into a separate branch based onphylogenetic analysis. All Moroccan IBV variants presented specific nucleotide and amino acid sequence insertions in the S1 gene in comparison to the Massachusetts vaccine strain that might be associated with the occurrence of clinical disease in vaccinated flocks. Further investigation related to cross protection and pathogenicity of this new genotype detected in this country are needed.

\section{Methods}

Tissue sampling from chickens with suspected IBV infection

Tissue samples from trachea, lungs, and kidneys were obtained from 10 birds from each flock, placed on ice, and transferred to the laboratory in sterile transport medium containing $5 \%$ antibiotics $(20,000 \mathrm{U} / \mathrm{ml}$ of penicillin, $10,000 \mu \mathrm{g} / \mathrm{ml}$ of streptomycin, and $5,000 \mu \mathrm{g} / \mathrm{ml}$ of kanamycin). These samples were used for virus isolation.

\section{Virus isolation}

Virus isolation was performed by inoculation of 9-11-dold, embryonated, specific pathogen-free hen's eggs with $200 \mu \mathrm{l}$ of $10 \%$ tissue homogenates. Eggs were incubated at $37{ }^{\circ} \mathrm{C}$ and candled daily. Embryos that died within $24 \mathrm{~h}$ after inoculation were discarded. On d 2 after inoculation, three eggs were chilled at $4{ }^{\circ} \mathrm{C}$ for $2 \mathrm{~h}$, and the allantoic fluids were harvested, centrifuged at $8,000 \mathrm{rpm}(\mathrm{xxx} \times g)$ for $15 \mathrm{~min}$, and stored at $-80{ }^{\circ} \mathrm{C}$. The remaining eggs were further incubated for 5 more $d$ and observed for typical embryonic lesions of IBV infection, such as dwarfing, stunting, and curling. Stored allantoic fluids were further passaged three times in specific pathogen-free eggs; the allantoic fluids were 
harvested and tested for the presence of IBV using rRTPCR.

\section{RNA extraction}

Viral RNA was extracted from infected allantoic fluids using the MagMax Express semi-automatic magnetic particle extractor (Life Technologies, Grand Island, NY) according to the manufacturer's instructions. Allantoic fluid samples and reagents were dispensed into X-well microplates prior to magnetic particle processing. After processing, each sample of extracted RNA recovered from the wells of the plates was subjected toRT-PCR amplification.

\section{Real time RT-PCR for nucleocapsid gene detection}

The oligonucleotides and the probe used for initial screening of IBV were described previously [31]. These oligonucleotides and the probe target the relatively conserved IBV N gene at nucleotide positions 741-1077 of the IBV Massachusetts H120 reference strain (GenBank accession number: AM260960). RNase free water and Newcastle disease virus strain (HB1) were included as negative controls. One-step RT-PCR was performed with $12.5 \mu \mathrm{l}$ of $2 \times$ RT-PCR buffer mix, $0.5 \mu$ lof $\mathrm{MgSO}_{4}$ ( $50 \mathrm{mmol} / \mathrm{l}), 0.5 \mu \mathrm{l}$ of Rox reference dye $(25 \mathrm{mmol} / \mathrm{l}$, Life Technologies), $0.5 \mu \mathrm{l}$ of Moloneymurine leukemia virus reverse transcriptase $(200 \mathrm{U} / \mu \mathrm{l}), 0.5 \mu \mathrm{lof}$ Taq DNA polymerase (Life Technologies), $0.5 \mu \mathrm{l}$ of primers $(0.2 \mu \mathrm{mol} /$ 1), $0.25 \mu \mathrm{l}$ of probe $(0.1 \mu \mathrm{mol} / \mathrm{l})$, and $5 \mu \mathrm{l}$ of RNA template to make a final volume of $25 \mu$ l.The reaction was carried out using a StepOne Plus real-time PCR system (Smart Cycler, Cepheid, Sunnyvale, CA) at $50{ }^{\circ} \mathrm{C}$ for $15 \mathrm{~min}, 95^{\circ} \mathrm{C}$ for $5 \mathrm{~min}$, and followed by 40 cycles of $9{ }^{\circ} \mathrm{C}$ for $15 \mathrm{~s} ; 60^{\circ} \mathrm{C}$ for $45 \mathrm{~s} ; 72{ }^{\circ} \mathrm{C}$ for $30 \mathrm{~s}$, and a final extension step of $74{ }^{\circ} \mathrm{C}$ for $5 \mathrm{~min}$. Amplifications were recorded and analyzed, and the threshold cycle $\left(\mathrm{C}_{\mathrm{t}}\right)$ was determined with StepOne software (Smart Cycler).

\section{RT-PCR for S1 gene detection and DNA sequencing}

Amplification of partialS1 gene sequences by RT-PCR was performed using the forward S1S15' mod (5'-TGA-AAACTG-AAC-AAA-AGA-3') and reverse S1CK2 (5'-CNGTRT-TRT-AYT-GRC-A-3') primers [32]. RT-PCR was performed using the Applied Biosystems kit protocol (Life Technologies). The RT reaction was performed in a $20 \mu \mathrm{l}$ reaction mixture containing $2 \mu \mathrm{l}$ of buffer (10x), $2.5 \mu \mathrm{l}$ of $\mathrm{MgCl}_{2}(25 \mathrm{mmol} / \mathrm{l}), 2.5 \mu \mathrm{l}$ of dNTP $(10 \mathrm{mmol} / \mathrm{l}), 0.75 \mu \mathrm{l}$ of each primer $(10 \mu \mathrm{mol} / \mathrm{l}), 10.2 \mu \mathrm{l}$ of sterilized water, $0.5 \mu \mathrm{l}$ of RNAase inhibitor $(20 \mathrm{U} / \mu \mathrm{l}), 0.3 \mu \mathrm{l}$ of RT $(50 \mathrm{U} / \mu \mathrm{l})$, and $0.5 \mu \mathrm{l}$ of Gold Taq polymerase $(5 \mathrm{U} / \mu \mathrm{l})$. The PCR products were analyzed on a $1 \%$ agarose gel.

Partial RT-PCR products of the S1 gene (700 bp) containing HVR1, HVR2, and HVR3 were purified using the Gene Clean Kit (ExoSAP-IT, Affymetrix, Santa Clara,
CA) according to the manufacturer's instructions. Purified PCR products were used as templates for sequencing using the BigDye ${ }^{\circ}$ Terminator v1.1 Cycle Sequencing Kit (Life Technologies). The second purification step was performed using the Big Dye XTerminator Purification Kit (Life Technologies). Purified PCR products were sequenced from both directions using the same primers (S15' mod and CK2).

\section{Nucleotide sequence and deduced amino-acid-sequence analyses}

Assembly and analysis of sequence data were conducted using the BioEdit Software version 5.0.9 [33]. The opensource BLAST program (National Center for Biotechnology Information, Bethesda MD, http://blast.ncbi.nlm.nih.gov/ Blast.cgi) was used for sequence comparison. Nucleotide sequence and deduced amino acid sequences were aligned using ClustalW and MEGA software Version 6.0 [34]. Phylogenetic analyses and tree construction for partial S1 glycoprotein gene sequences were generated using the neighbor-joining method with 1,000 bootstrap replicates with MEGA.

\section{Genbank accession numbers of reference IBV variants}

Ark/C6d (EU283056); D274 (X15832); Egypt/Beni-Suef/01 (JX174183); Egypt/SCU-14/2013-1 (KF731612); H120 (M21970); Italy-02 (AJ457137); Italy It/497/02-1 (DQ90 1377); Ma5 (AY561713); QX (AF193423); Spain/04/22-1 (DQ386100); Tunisia TN296/07 (FJ716133); Tunisia TN556/07 (FJ716132); Spain/05/866 (DQ386102); Spain/ 04/221 (DQ386103); Isolate Q1 (AF286302); SARS (D14056); Strain 04/91 (AF093794);NGA/A116E7/2006 (FN430415).

\section{Abbreviations}

IBV: Infectious bronchitis virus; IBV/Morocco/01: gammaCoV/chicken/ Morocco/I01/2011; IBV/Morocco/30: gammaCoV/chicken/Morocco/I30/2010; IBV/Morocco/38: gammaCoV/chicken/Morocco/I38/2013; IB: Infectious bronchitis; S: Spike; M: Membrane; N: Nucleocapsid; HVR: Hypervariable regions.

\section{Competing interests}

The authors declare that they have no competing interests.

\section{Authors' contributions}

SF participated in the design of the study, performed the molecular genetic studies andthe phylogenetic sequence alignment,and drafted the manuscript. MD participated in the phylogenetic analysis and helped to draft the manuscript. CL participated in virus isolation. SIK participated in virus sequencing. JHK critically editedand corrected the manuscript. SK helped with sequence alignment. KK helped withvirus sampling and isolation. MEH participated in the design of the study, and helped to draft and improve the manuscript. MME conceived of the study, participated in its design and coordination, and helped to draft the manuscript. All authors read and approved the final manuscript.

\section{Acknowledgments}

We thank Laura Bollinger (Integrated Research Facility at Fort Detrick) for providing Technical Writing Services in critically editing this manuscript on behalf of Battelle Memorial Institute. The content of this publication does not necessarily reflect the views or policies of the US Department of Health 
and Human Services (DHHS) or of the institutions and companies affiliated with the authors. This work was funded in part through Battelle Memorial Institute's prime contract with the US National Institute of Allergy and Infectious Diseases (NIAID) under Contract No. HHSN272200700016l. A subcontractor to Battelle Memorial Institute who performed this work is J.H.K., an employee of Tunnell Government Services, Inc.

The Agronomic and Veterinary Institute Hassan II, Rabat, Morocco, Ministry of Higher Education of Morocco, University Hassan II Mohammedia - Casablanca, Mohammedia, Morocco, and the Société de Produits Biologiqueset Pharmaceutiques Vétérinaires (Biopharma), Rabat, Morocco sponsored the screening and sequencing of different samples.

\section{Author details}

${ }^{1}$ Unité de Pathologie Aviaire, Département de Pathologie et Santé Publique Vétérinaire, Institut Agronomique et Vétérinaire Hassan II, Rabat 10000, Morocco. ${ }^{2}$ Société de Produits Biologiques et Pharmaceutiques Vétérinaires, Rabat 10000, Morocco. ${ }^{3}$ Institut National de la Recherche Agronomique, Unité Mixte de Recherche 1225 Interaction hôtes-agents pathogènes, F-31076 Toulouse, France. ${ }^{4}$ Université de Toulouse, Institut National Polytechnique, Ecole Nationale Vétérinaire de Toulouse, Unité Mixte de Recherche 1225 Interaction hôtes-agents pathogènes, F-31076 Toulouse, France. ${ }^{5}$ Laboratoire de Biotechnologie Microbienne, Université Sidi Mohamed Ben Abdellah, Fez 30000, Morocco. Integrated Research Facility at Fort Detrick, National Institute of Allergy and Infectious Diseases, National Institutes of Health, B-8200 Research Plaza, Fort Detrick, Frederick, MD 21702, USA. 'Genomique Cellulaire et Techniques Moléculaire Investigations, Université Moulay Ismail, Meknès 50000, Morocco. ${ }^{8}$ Laboratoirede Virologie, Microbiologie et Qualité/ETB- Faculté des Sciences et Techniques, Mohammedia, Université Hassan II- Casablanca, Mohammedia 20650, Morocco.

\section{Received: 22 February 2015 Accepted: 17 July 2015}

\section{Published online: 04 August 2015}

\section{References}

1. Cavanagh D. Severe acute respiratory syndrome vaccine development: experiences of vaccination against avian infectious bronchitis coronavirus. Avian Pathol. 2003:32:567-82.

2. Cavanagh D. Coronaviruses in poultry and other birds. Avian Pathol. 2005:34:439-48.

3. Jackwood MW. Review of infectious bronchitis virus around the world. Avian Dis. 2012:56:634-41.

4. Boursnell ME, Brown TD, Foulds IJ, Green PF, Tomley FM, Binns MM. Completion of the sequence of the genome of the coronavirus avian infectious bronchitis virus. J Gen Virol. 1987;68:57-77.

5. Cavanagh D. Coronavirus IBV: structural characterization of the spike protein. J Gen Virol. 1983;64:2577-83.

6. Cavanagh D. Coronavirus avian infectious bronchitis virus. Vet Res. 2007;38:281-97.

7. Cavanagh D, Davis PJ, Mockett AP. Amino acids within hypervariable region 1 of avian coronavirus IBV (Massachusetts serotype) spike glycoprotein are associated with neutralization epitopes. Virus Res. 1988;11:141-50.

8. Kant A, Koch G, van Roozelaar DJ, Kusters JG, Poelwijk FA, van der Zeijst BA. Location of antigenic sites defined by neutralizing monoclonal antibodies on the S1 avian infectious bronchitis virus glycopolypeptide. J Gen Virol. 1992;73:591-6.

9. Lee CW, Hilt DA, Jackwood MW. Typing of field isolates of infectious bronchitis virus based on the sequence of the hypervariable region in the S1 gene. J Vet Diagn Invest. 2003;15:344-8.

10. Wang L, Junker D, Hock L, Ebiary E, Collisson EW. Evolutionary implications of genetic variations in the $\mathrm{S} 1$ gene of infectious bronchitis virus. Virus Res. 1994;34:327-38.

11. De Wit J, Cook JK, Van der Heijden HM. Infectious bronchitis virus variants: a review of the history, current situation and control measures. Avian Pathol. 2011:40:223-35.

12. Alvarado I, Villegas $P$, Mossos N, Jackwood M. Molecular characterization of avian infectious bronchitis virus strains isolated in Colombia during 2003. Avian Dis. 2005;49:494-9.

13. Gelb Jr J, Wolff JB, Moran CA. Variant serotypes of infectious bronchitis virus isolated from commercial layer and broiler chickens. Avian Dis. 1991;35:82-7.
14. Lee CW, Jackwood MW. Evidence of genetic diversity generated by recombination among avian coronavirus IBV. Arch Virol. 2000;145:2135-48.

15. El-Houadfi M, Jones RC, Cook JK, Ambali AG. The isolation and characterisation of six avian infectious bronchitis viruses isolated in Morocco. Avian Pathol. 1986;15:93-105.

16. Alarabi MAH: A field study of kidney disease among the broiler flocks in Morocco and its relationship to infectious bronchitis virus. Ph.D thesis. Agronomic and Veterinary Institute Hassan II, Rabat, Morocco; 2004.

17. El Bouqdaoui M, Mhand R, Bouayoune H, Ennaji M. Genetic grouping of nephropathogenic avian infectious bronchitis virus isolated in Morocco. Int J Poult Sci. 2005:4:721-7.

18. Jones RC. Viral respiratory diseases (ILT, aMPV infections, IB): are they ever under control? Br Poult Sci. 2010;51:1-11. doi:10.1080/00071660903541378.

19. Dolz R, Pujols J, Ordonez G, Porta R, Majo N. Molecular epidemiology and evolution of avian infectious bronchitis virus in Spain over a fourteen-year period. Virology. 2008;374:50-9.

20. Dolz R, Pujols J, Ordonez G, Porta R, Majo N. Antigenic and molecular characterization of isolates of the Italy 02 infectious bronchitis virus genotype. Avian Pathol. 2006;35:77-85.

21. Domingo E, Martinez-Salas E, Sobrino F, de la Torre JC, Portela A, Ortin J, et al. The quasispecies (extremely heterogeneous) nature of viral RNA genome populations: biological relevance-a review. Gene. 1985:40:1-8.

22. Lai MM, Cavanagh D. The molecular biology of coronaviruses. Adv Virus Res. 1997:48:1-100

23. Kusters JG, Niesters HG, Lenstra JA, Horzinek MC, van der Zeijst BA. Phylogeny of antigenic variants of avian coronavirus IBV. Virology. 1989;169:217-21.

24. Kingham BF, Keeler Jr CL, Nix WA, Ladman BS, Gelb Jr J. Identification of avian infectious bronchitis virus by direct automated cycle sequencing of the S-1 gene. Avian Dis. 2000;44:325-35.

25. Cavanagh D, Davis PJ, Cook JK, Li D, Kant A, Koch G. Location of the amino acid differences in the $\mathrm{S1}$ spike glycoprotein subunit of closely related serotypes of infectious bronchitis virus. Avian Pathol. 1992;21:33-43.

26. Kusters JG, Jager EJ, Niesters HG, van der Zeijst BA. Sequence evidence for RNA recombination in field isolates of avian coronavirus infectious bronchitis virus. Vaccine. 1990;8:605-8.

27. Cavanagh D, Elus MM, Cook JK. Relationship between sequence variation in the S1 spike protein of infectious bronchitis virus and the extent of crossprotection in vivo. Avian Pathol. 1997;26:63-74.

28. Ignjatovic J, Galli L. The S1 glycoprotein but not the $\mathrm{N}$ or M proteins of avian infectious bronchitis virus induces protection in vaccinated chickens. Arch Virol. 1994:138:117-34.

29. Wang $\mathrm{CH}$, Huang YC. Relationship between serotypes and genotypes based on the hypervariable region of the $\mathrm{S} 1$ gene of infectious bronchitis virus. Arch Virol. 2000;145:291-300.

30. Moore KM, Jackwood MW, Hilt DA. Identification of amino acids involved in a serotype and neutralization specific epitope within the s1 subunit of avian infectious bronchitis virus. Arch Virol. 1997;142:2249-56.

31. Meir R, Maharat O, Farnushi Y, Simanov L. Development of a real-time TaqMan RT-PCR assay for the detection of infectious bronchitis virus in chickens, and comparison of RT-PCR and virus isolation. J Virol Methods. 2010;163:190-4.

32. Eterradossi N, Britton P: Avian infectious bronchitis, in: Biological Standards Commission (Ed.), Manual of Diagnostic Tests and Vaccines for Terrestrial Animals. World Organisation for Animal Health, Paris, FR. http://www.oie.int/ fileadmin/Home/eng/Health_standards/tahm/2.03.02_AlB.pdf. (Accessed May 2, 2014).

33. Hall TA. BioEdit: a user-friendly biological sequence alignment editor and analysis program for Windows 95/98/NT. Nucleic Acids Symp. 1999;41:95-8.

34. Tamura K, Stecher G, Peterson D, Filipski A, Kumar S. MEGA6: Molecular Evolutionary Genetics Analysis version 6.0. Mol Biol Evol. 2013;30:2725-9. 